\title{
Foraging success, kleptoparasitism and feeding techniques in scavenging seabirds: does crime pay?
}

\author{
Stefan Garthe ${ }^{1,2, *} \&$ Ommo Hüppop ${ }^{2}$ \\ 'Institut für Meereskunde, Abt. Meereszoologie; Düsternbrooker Weg 20, \\ D-24105 Kiel, Germany \\ 2 Institut für Vogelforschung "Vogelwarte Helgoland", Inselstation; \\ P.O. Box 1220, D-27494 Helgoland, Germany
}

\begin{abstract}
Scavenging seabirds in the North Sea exploit discards with different success and by different feeding techniques. Northern gannet (Sula bassana) had the highest foraging success index, followed by lesser black-backed gull (Larus fuscus) and black-legged kittiwake (Rissa tridactyla). Northern fulmar (Fulmarus glacialis), mew gull (Larus canus) and black-headed gull (Larus ridibundus) were the least successful species. Ranking species according to the ratio of fish stolen from vs. lost to other species (= robbery index), northern gannet, great black-backed gull (Larus marinus) and great skua (Catharacta skua) were at the top, northern fulmar and black-legged kittiwake at the bottom. Varying compositions of the feeding flocks influenced the foraging success of the species significantly. Both body length and body mass of the birds can well explain species order in the robbery index but not in the foraging success index. Our bypothesis that the most successful species employ particular feeding techniques and/or exhibit the strongest kleptoparasitic abilities could be confirmed to a large extent but not totally. During reduced overall feeding rates, some less successful species and/or species with weaker kleptoparasitic capabilities fared better than during intense feeding rates as predicted, some others did not.
\end{abstract}

\section{INTRODUCTION}

Discards supplied by commercial fisheries form a substantial part of the diet of many scavenging seabird species, most notably demonstrated in great skuas Catharacta skua (e.g. Hamer et al., 1991) and large Larus gulls (e.g. Noordhuis \& Spaans, 1992; Ruiz et al., 1996). In consequence, it is not surprising that the availability of this type of food can strongly influence not only the feeding ecology of the species but also their daily activity (Oro, 1995), predation rates (Russell \& Montevecchi, 1996), breeding phenology and reproductive output (e.g. Oro et al., 1996). Since (a) the sizes of discard items taken by birds broadly overlap, (b) the numbers of ship-followers are often high and (c) interactions between individuals are sometimes numerous, it is concluded that competition often occurs between scavenging species when feeding near trawlers (see Furness, 1992 for review). Flock composition, however, is known to affect a species' foraging success whether

\footnotetext{
- Addressee for all correspondence: Dr. Stefan Garthe, Institut für Meereskunde, Düsternbrooker Weg 20, D-24105 Kiel, Germany; Tel. +4943159739 38; Fax +49431597 3994; E-mail sgarthe@ifm. uni-kiel.de
} 
it forages on natural food (e.g. Porter \& Sealy, 1982; Shealer \& Burger, 1993) or on fishery waste (e.g. Furness et al., 1992; Garthe \& Hüppop, 1994). Seabirds might therefore try to employ particular strategies when feeding near trawlers, which may lead to differences in behaviour and prey choice (e.g. Hudson \& Furness, 1989; Camphuysen et al., 1995). Kleptoparasitism, generally considered to be either a type of interspecific aggression (e.g. Thompson, 1986) or a response to food shortage (e.g. Oro, 1996), is particularly facilitated in feeding assemblages found around fishing vessels (sensu Brockmann \& Barnard, 1979).

We hypothesize that those bird species that are the most successful in obtaining discards either employ particular feeding techniques or exhibit the strongest kleptoparasitic abilities. These two assumptions will be tested in this paper. Furthermore, we predict that, during periods of reduced overall feeding rates, less successful species and/or species with weaker kleptoparasitic capabilities fare better than during periods of intense feeding rates.

\section{MATERIAL AND METHODS}

Experiments on seabirds feeding on discards were carried out from on board the German fishery research vessel "Walther Herwig" (Federal Research Board for Fisheries, Hamburg). Two observers participated in each of four cruises in the central and northern North Sea: 12th May to 8th June 1992, 14th July to 3rd August 1992, 10th to 20th June 1993 and 16th to 21 st July 1993. These journeys were part of the International Bottom Trawl Survey, a sampling scheme to examine the distribution of demersal fish in the North Sea recommended by ICES (= International Council for the Exploration of the Sea). For more details see Garthe \& Hüppop (1994). For analyses, data from all journeys were pooled because the experimental methods were identical and the studies were conducted at a similar time of year.

Discard experiments were carried out using subsamples of the total fish catch. The subsamples closely matched the total catch with regard to both species composition and length of prey. Before being discarded, fish were identified to species, and their total length measured. The fate of each fish, thrown overboard singly, was recorded. It was noted whether a fish was swallowed instantly, stolen by another bird, or whether it sank (see Garthe \& Hüppop, 1994 for more details).

$\mathrm{S} \mathrm{h}$ i p - f o l l o w e r s: We estimated the numbers of birds attending the vessel during the trawls. For each species, the maximum number from setting out the net until the end of processing of the haul was recorded. In this study, nine bird species regularly following the vessel were considered; other species were rare (Garthe \& Hüppop, 1994).

F or a g in $\mathrm{g}$ s u c ces s: As a measure of the foraging success of birds we calculated the foraging success index (FSI). Here, only the final consumer of the fish was taken into account. The FSI is expressed as a logarithm to match a normal distribution of the data:

FSI $=\log$ (Ipercent of all fish that were swallowed by a species / percent of all shipfollowers that were this species] +1 ).

$\mathrm{K}$ le p t o p a r a s it is $\mathrm{m}$ : We calculated a robbery index (RI) by quantifiying the interspecific interactions that took place when fish were discarded (Camphuysen et al., 1995):

$\mathrm{RI}$ = number of fish stolen by a species / number of fish stolen from this species. 
Proportion of discards consumed: The percentage of discards taken by birds differed greatly. There is reason to believe that hunger, among several other factors, influences this percentage; consequently, hunger was taken into account. Since flatfish are rarely swallowed (Camphuysen et al., 1995; Garthe \& Hüppop, 1994) and were discarded only in low numbers due to the low availability in the catches, we calculated the proportion of discards consumed (PDC) for roundfish only. To avoid strong biases, we neglected discard experiments with fewer than 30 fish discarded. The variability of the PDC was relatively little affected by the type of roundfish which we discarded: fish that were usually preferred by the scavengers received also less attention when the PDC was low.

$\mathrm{PDC}($ in $\%)=($ number of items swallowed / number of items offered) $\times 100$.

Correlations between the absolute and relative numbers of ship-followers and FSI were investigated for the four species exhibiting the most characteristic feeding techniques and particularly high or low FSI values. In order to compensate for the multiplicity of significance tests, Beal \& Khamis (1991) strongly recommend adjusting the level of significance according to the Bonferroni method in the case of simultaneous inferences. We therefore corrected the level of significance by dividing $\alpha$ (the probability of a type I error) by 7 (number of tests to explain the FSI of each species considered). Hence, the significance level is lowered to $0.05 / 7=0.007$.

\section{RESULTS}

\section{Foraging success}

Scavenging species differed significantly in their foraging success (Table 1). The northern gannet (Sula bassana, hereafter gannet) was the most successful species, followed by lesser black-backed gull (Larus fuscus) and black-legged kittiwake (Rissa tridactyla, hereafter kittiwake). Mew gull (Larus canus) and black-headed gull (Larus ridibundus) were the least successful species. The species order changed somewhat for high and low proportions of discards consumed (PDC), which we consider to reflect different stages of interest in food (e.g. repletion). However, the gannet was always the most successful species (Table 1). At high PDC, the great skua (Catharacta skua) had the second highest FSI, while northern fulmar (Fulmarus glacialis, hereafter fulmar) and black-headed gull the lowest. The foraging successes of gannet, kittiwake and mew gull were significantly higher for trawls with high PDC. Comparing FSI between PDC of $\leq 60 \%$ and of $90-100 \%$, the differences become also significant for fulmars $(t=2.13$, $\mathrm{p}<0.05$ ), with FSI significantly higher at trawls with low PDC.

The FSI of gannets and great skuas increase significantly with increasing PDC whereas the FSI of fulmars decreased significantly (Table 2).

FSI and body dimensions of the birds did not correlate significantly (Table 3 ). For example, kittiwakes were much more successful than expected from their body mass.

The FSI of fulmar, gannet, great skua and kittiwake were correlated with some of the absolute numbers and percentages of ship-following species (Table 4). 
Table 1. Foraging success indices (= FSI, for definition see "Methods") of nine bird species feeding on discards in different situations; $n=$ number of trawls

\begin{tabular}{|c|c|c|c|c|c|c|c|c|}
\hline & \multicolumn{8}{|c|}{ Proportion of discards consumed } \\
\hline & \multicolumn{2}{|c|}{ Total } & \multicolumn{2}{|c|}{$90-100 \%$} & \multicolumn{2}{|c|}{$\leq 75 \%$} & \multicolumn{2}{|c|}{ Null hyp. II } \\
\hline & FSI & $\mathrm{n}$ & FSI & $\mathbf{n}$ & FSI & $\mathrm{n}$ & & \\
\hline Gannet & 0.551 & 128 & 0.704 & 53 & 0.385 & 39 & $t=-4.50$ & $\mathrm{p}<0.001$ \\
\hline Lesser black-backed gull & 0.284 & 123 & 0.307 & 41 & 0.217 & 45 & $\mathrm{t}=-1.70$ & n.s. \\
\hline Kittiwake & 0.281 & 155 & 0.317 & 58 & 0.227 & 54 & $t=-2.30$ & $\mathrm{p}<0.05$ \\
\hline Herring gull & 0.271 & 101 & 0.285 & 37 & 0.279 & 35 & $t=-0.08$ & n.s. \\
\hline Great black-backed gull & 0.262 & 44 & 0.275 & 19 & 0.167 & 17 & $t=-0.92$ & n.s. \\
\hline Great skua & 0.239 & 32 & 0.364 & 19 & 0 & 5 & not tested & \\
\hline Fulmar & 0.211 & 161 & 0.194 & 60 & 0.232 & 56 & $t=1.44$ & n.s. \\
\hline Mew gull & 0.186 & 38 & 0.260 & 17 & 0.070 & 13 & $t=-2.13$ & $\mathrm{p}<0.05$ \\
\hline Black-headed gull & 0.117 & 26 & 0.149 & 7 & 0.039 & 13 & $t=-1.25$ & n.s. \\
\hline Null hyp. I & $\begin{array}{l}F=1 \\
p<0\end{array}$ & $\begin{array}{l}18.75 \\
0001\end{array}$ & $\begin{array}{l}\mathrm{F}=1 \\
\mathrm{p}<0 .\end{array}$ & & $\begin{array}{l}\mathrm{F}= \\
\mathrm{p}<\end{array}$ & & & \\
\hline \multicolumn{9}{|c|}{$\begin{array}{l}\text { Null hypothesis I: FSI of all species is not different (one way ANOVA) } \\
\text { - > rejected: FSI is different for all species at all, high and low PDC }\end{array}$} \\
\hline \multicolumn{9}{|c|}{$\begin{array}{l}\text { Null hypothesis II: FSI of each species is not different at high and low PDC (t-test) } \\
->\text { accepted: FSI of lesser black-backed gull, herring gull, great black-backed gull, great skua, } \\
\text { fulmar and black-headed gull are not different at high and low PDC } \\
->\text { rejected: FSI of gannet, kittiwake and mew gull are different at high and low PDC }\end{array}$} \\
\hline
\end{tabular}

\section{Kleptoparasitism}

Stealing discarded fish from other birds was frequently observed. Figure 1 demonstrates all interactions observed between the seven most common ship-following species. The fulmar was the species with most interactions, stealing many fish from kittiwakes and losing many fish to gannets and large gulls.

Table 2. Spearman rank correlation between foraging success indices (FSI) and proportion of discards consumed (PDC) of nine scavenging seabird species

\begin{tabular}{|lccl|}
\hline Species & $\mathrm{r}_{\mathrm{s}}$ & Sample size & Significance \\
\hline Fulmar & -0.157 & 161 & $\mathrm{p}<0.05$ \\
Gannet & 0.314 & 128 & $\mathrm{p}<0.001$ \\
Great skua & 0.501 & 32 & $\mathrm{p}<0.01$ \\
Black-headed gull & 0.289 & 26 & n.s. \\
Mew gull & 0.277 & 38 & n.s. \\
Lesser black-backed gull & 0.171 & 123 & n.s. \\
Herring gull & 0.077 & 101 & n.s. \\
Great black-backed gull & 0.212 & 44 & n.s. \\
Kittiwake & 0.142 & 155 & n.s. \\
\hline
\end{tabular}


Table 3. Robbery indices (= RI) and foraging success indices (= FSI; for definitions see "Methods") of the nine most numerous bird species and their correlation with body mass (after Bezzel, 1985) and body length (after Cramp \& Simmons, 1977, 1983)

\begin{tabular}{|c|c|c|c|c|}
\hline Species & FSI & RI & $\begin{array}{c}\text { Body Mass } \\
\text { (g) }\end{array}$ & $\begin{array}{l}\text { Body Length } \\
\text { (mm) }\end{array}$ \\
\hline Gannet & 0.551 & 13.9 & 3015 & 935 \\
\hline Lesser black-backed gull & 0.284 & 1.9 & 792 & 595 \\
\hline Kittiwake & 0.281 & 0.1 & 371 & 390 \\
\hline Herring gull & 0.271 & 2.5 & 1061 & 610 \\
\hline Great black-backed Gull & 0.262 & 6.7 & 1600 & 710 \\
\hline Great skua & 0.239 & 4.5 & 1432 & 555 \\
\hline Fulmar & 0.211 & 0.4 & 781 & 475 \\
\hline Mew gull & 0.186 & 1.2 & 396 & 410 \\
\hline Black-headed gull & 0.117 & 0.2 & 261 & 355 \\
\hline $\begin{array}{l}\text { Spearman rank correlation } \\
1 \text {. Between FSI and } \\
\text { - body mass: } r_{\mathrm{s}}=0.550, \\
\text { - body length: } r_{\mathrm{s}}=0.650, \mathrm{c}\end{array}$ & $\begin{array}{l}\text { n.s. } \\
\text { n.s. }\end{array}$ & & & \\
\hline $\begin{array}{l}\text { 2. Between RI and } \\
\text { - body mass: } r_{s}=0.967, c \\
\text { - body length: } r_{s}=0.917,\end{array}$ & $\begin{array}{l}p<0.001 \\
p<0.01\end{array}$ & & & \\
\hline
\end{tabular}

Table 4. Spearman rank correlations between foraging success indices (FSI) of fulmar ( $\mathrm{n}=161$ trawls), gannet ( $n=128$ trawls), great skua ( $n=32$ trawls) and kittiwake ( $n=155$ trawls) and (a) the absolute number of single ship-following species, (b) the percentage of single ship-following species. Only significant correlations are listed; see text for statistical assumptions

\begin{tabular}{|c|c|c|c|}
\hline \multirow{2}{*}{$\begin{array}{l}\text { (a) Absolute number } \\
\text { of ship-followers } \\
\text { Species }\end{array}$} & \multirow[b]{2}{*}{$r_{s}$} & \multicolumn{2}{|c|}{$\begin{array}{l}\text { (b) Percentage of } \\
\text { all ship-followers }\end{array}$} \\
\hline & & Species & $r_{s}$ \\
\hline $\begin{array}{l}\text { F S I ( f u l m a r ) : } \\
\text { gannet } \\
\text { lesser black-backed gull }\end{array}$ & $\begin{array}{l}-0.254 \\
-0.273\end{array}$ & gannet & -0.250 \\
\hline $\begin{array}{c}\text { FS I (g a n n e t ) : } \\
\text { fulmar } \\
\text { gannet } \\
\text { kittiwake }\end{array}$ & $\begin{array}{l}+0.391 \\
+0.454 \\
+0.271\end{array}$ & gannet & +0.254 \\
\hline $\begin{array}{l}\text { FSI ( great skua ): } \\
\text { fulmar } \\
\text { FS I ( kit ti wake): } \\
\quad \text { fulmar } \\
\quad \text { lesser black-backed gull }\end{array}$ & $\begin{array}{l}+0.240 \\
-0.233\end{array}$ & & \\
\hline
\end{tabular}




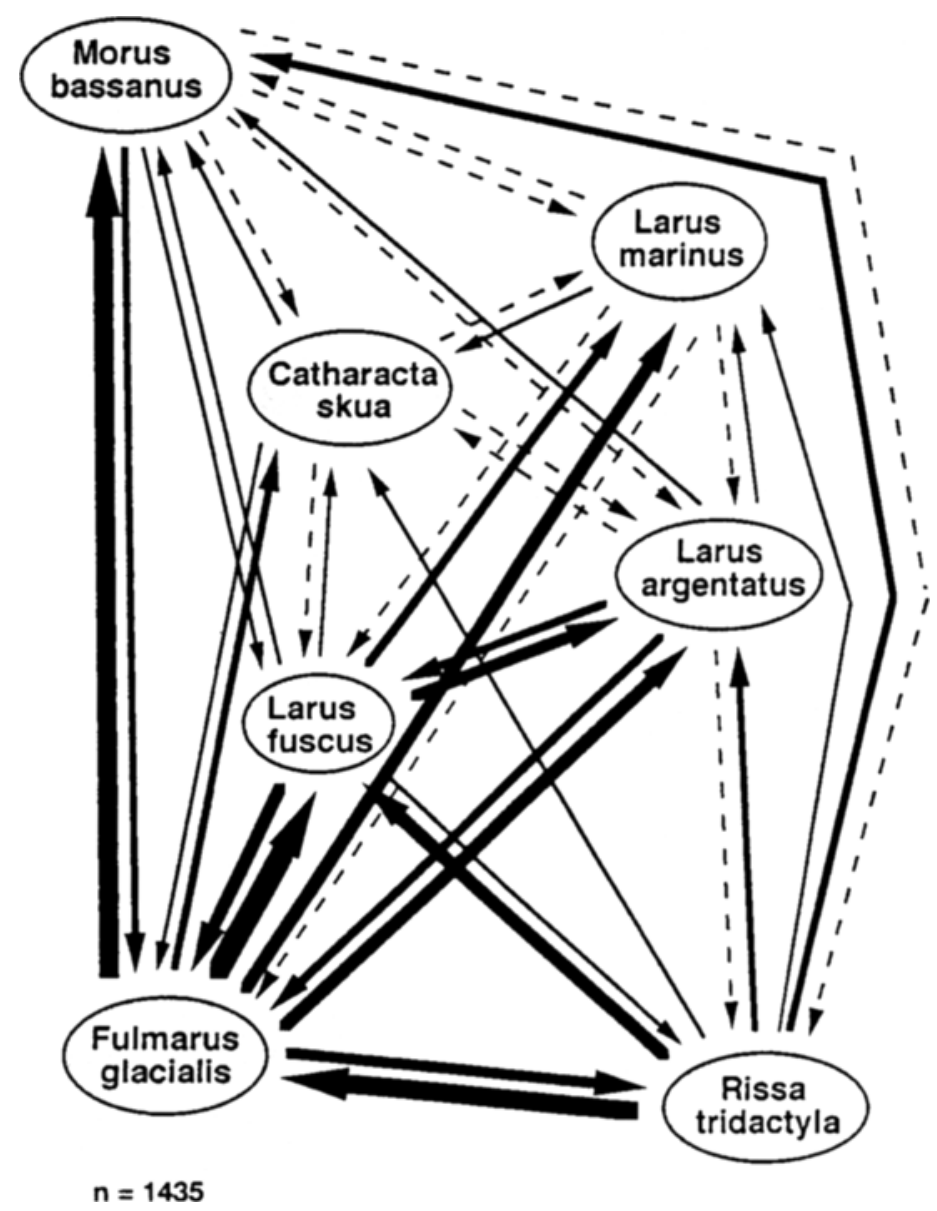

Fig. 1. Quantification of interactions between seven birds species. Arrow thickness is equivalent to the number of fish stolen (from dashed $=1-2$ interactions to the broadest arrows = more than 100 interactions), the arrows point at the species which stole the fish. Species at top of the figure have the highest robbery indices, those at the bottom the lowest

The robbery index (RI) was highest for the gannet, followed by the great blackbacked gull (Larus marinus) and the great skua (Table 5). The fulmar, black-headed gull and kittiwake had the lowest values. Regarding (high and low) PDC, the order was the same, and the numerical values similar. However, fulmars lost significantly fewer fish (or stole significantly more fish) when PDC was low. Interestingly, the species with the highest RI (gannet, great black-backed gull, great skua) hardly ever stole fish from one another.

Overall, the kleptoparasitic interactions did not occur randomly between the species involved. At all trawls and at high and low PDC, the differences between fish stolen and fish lost are highly significant. 
Table 5. Robbery indices (= RI; for definition, see "Methods") of nine bird species feeding on discards in different situations; $n=$ number of interactions

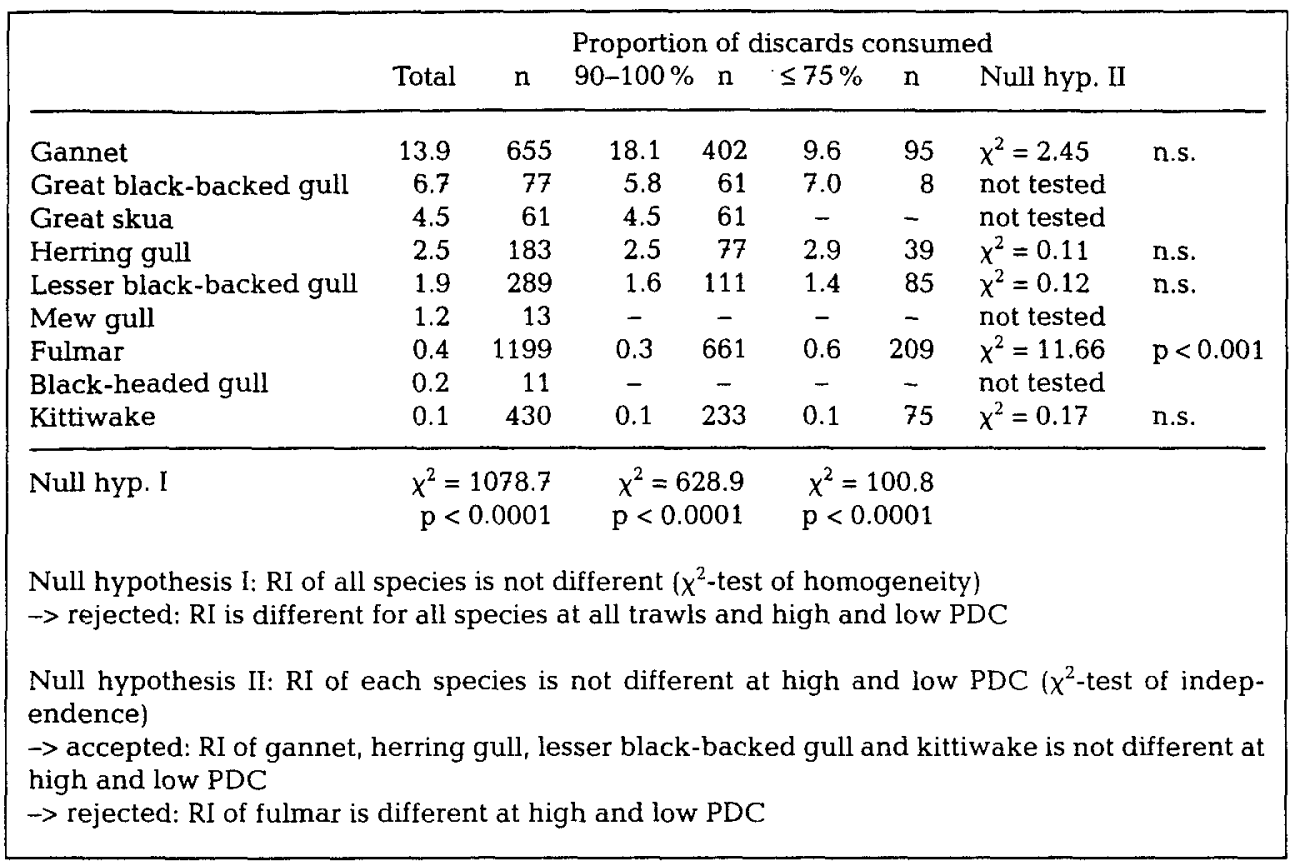

The ratio of interactions per roundfish consumed did not change much for different $\operatorname{PDC}\left(\chi^{2}=1.83\right.$, n.s., $\mathrm{p}=0.77$, Kruskal-Wallis H-test $)$.

\section{Feeding techniques}

$\mathrm{G}$ a $\mathrm{n} \mathrm{n}$ e $\mathrm{t}$ : This species was by far the most successful in utilizing discards. It was only less successful when other species occurred in (very) high numbers and especially when gannets themselves were present in particularly low numbers. Thus, their foraging success increased significantly when both their absolute and relative numbers as shipfollowers increased (Table 4). Since gannets take almost all discards by plunge-diving, there is a certain time lag between detecting and swallowing the food. This lag is the best and often the only chance for other species to obtain discards. Gannets steal discards from other species mostly on the water surface after having conducted plunge-dives but only very rarely in flight.

Ful m a r: On almost all occasions, and in contrast to all other species, the majority of fulmars swim behind or around the vessel. Thus, they can obtain fish only if they swim near the place where the discards are discharged. Swimming makes them very vulnerable to physically strong competitors such as large gulls, great skuas and gannets. Indeed, they lose a considerable amount of fish to these species (Fig. 1). Fulmars suffered significantly less from kleptoparasitic interactions when the feeding pressure (measured 
as the proportion of discards consumed) was low than they did when high proportions of discards were consumed (Table 5).

Great $\mathrm{skua}$ and great b lack - ba cked gull: Both species rarely take fish directly from the water surface. Instead, they primarily try to steal it from other, generally smaller, species such as fulmars and lesser black-backed gulls. These species also stay mostly at a greater distance from the ship.

Ki t t i w a ke: Kittiwakes do not swallow large fish (Garthe \& Hüppop, 1994; Camphuysen et al., 1995). Hence, they focus only on a small part of the catch which seems to be less attractive for the largest bird species. Best opportunities occur when the net is hauled because small fish can then be taken directly out of the net meshes. Since kittiwakes fare worst in interactions, they have to catch and swallow the fish rapidly. Indeed, this species is able to pick up the discards very quickly due to its excellent manoeuvrability (high flight speed, agility and small body size).

Lesser black-backedgulls and herring gulls Larus argentatus use an intermediate strategy between great skuas/great black-backed gulls and kittiwakes.

\section{DISCUSSION}

Firstly, we hypothesized that those bird species that are the most successful in obtaining discards employ particular feeding techniques and/or exhibit the strongest kleptoparasitic abilities. This hypothesis can be confirmed to a large extent but not totally. First of all, the FSI cannot be explained by bird body dimensions alone (Table 3). Hence, it is obvious that the species' techniques of feeding on discards differ in their success. For this reason, a discussion on the different foraging behaviour employed by various species while feeding on discards was appropriate (see also Dändliker \& Mülhauser, 1988; Hudson \& Furness, 1989; Camphuysen, 1993). The species ranking first in FSI, the gannet (conducting plunge-dives), and the species ranking third, the kittiwake (with apparently the highest flight manoeuvrability), catch food by particular feeding techniques quite different from the techniques used by those species that specialise in kleptoparasitism, e.g. the great skua. Two other species ranking also relatively high, the lesser black-backed gull and the herring gull, can be considered as generalists because they use an intermediate strategy when scavenging on discards. Kleptoparasitism does not influence foraging success significantly (FSI correlated with RI: $r_{5}=0.433$, n.s., Spearman rank correlation) suggesting that, in this case, "crime does not pay".

That does not mean, however, that foraging success is not influenced by kleptoparasitism, which is generally an important feeding technique in skuas and gulls (Furness, 1987). Camphuysen et al. (1995) found that $17 \%$ of all roundfish and $22 \%$ of all flatfish were handled by more than one bird. Most of these events can be attributed to the fact that birds steal fish from one another. The number of interactions was particularly high for large fish since these are most difficult to swallow rapidly. Since RI is almost perfectly correlated with body measurements of the scavengers (Table 3), it is obvious that relatively weak species such as kittiwake but also fulmar and lesser blackbacked gull do better by avoiding these interactions. Recent investigations indeed indicate that fulmars attend trawlers less in autumn and winter when usually large numbers of ship-following herring gulls invade the North Sea (Camphuysen \& Garthe, 1997). 
Varying compositions of the feeding flocks at the trawler apparently influence FSI of some species. Although analyses of correlations between FSI and numbers of shipfollowers are somewhat impaired by heterogeneity in the data (strongly varying numbers of species and individuals, time of year/breeding stage and region), the correlations appear to be not only statistically valid but also biologically relevant. Thus, fulmars fare worse in the presence of gannets and lesser black-backed gulls to which they lose many discards but from which they steal considerably less. Likewise, gannets and great skuas, but also kittiwakes, benefit from the presence of fulmars. Similarly, Furness et al. (1992) observed that the foraging success of herring gulls was remarkably lowered by the presence of gannets near fishing vessels in the Clyde, west Scotland. Apparently, the herring gulls moved away from the trawlers, possibly flying to refuse tips, when confronted with increasing competition from gannets.

Secondly, we hypothesized that, during periods of reduced overall feeding rates, less successful species and/or species with weaker kleptoparasitic capabilities fare better than during periods of intense feeding rates. This hypothesis can partly be corroborated. Thus fulmars, which obtained relatively low values in both FSI and RI, were significantly more successful when feeding pressure, measured as PDC, decreased. Also, they exhibited a higher robbery index when PDC was low. On the other hand, mew gulls were significantly more successful during low PDC (Table 1) although PDC and FSI were not significantly correlated. Furthermore, kittiwakes reached the same low RI values during both categories of feeding pressure (Table 5).

How reliable are then our data on foraging success? Two topics originating from the methods employed might have affected the results on foraging success: FSI is probably biased somewhat towards the smaller, more agile scavengers flying close to the ship. This is because we singly discarded fish from the stem which is an unusual situation for commercial fisheries. Care was taken, however, to throw the fish as close to the net as possible when it was hauled in and into the stream of discards when the bulk of the catch was discharged. In addition, we have no information about the turnover time of birds following the ships. Kittiwakes may attend ships for many hours (Erikstad et al., 1988) whereas gannets occur there chiefly for only short time periods (Hudson \& Furness, 1989). This could seriously bias the FSI: high turnover rates mean that a large number of individuals are involved, hence the FSI would be lower if corrected appropriately.

In conclusion, the results demonstrate that scavenging seabird species utilize discards provided by fisheries throughout the whole North Sea to very different degrees. Whereas the species order obtained by the robbery index can be well explained by bird body dimensions, the foraging success index cannot be explained in this way. This means that species that have lower kleptoparasitic capabilities can nevertheless obtain a high foraging success by using particular feeding techniques.

Acknowledgements. The "Bundesforschungsanstalt für Fischerei" (Federal Research Board for Fisheries) in Hamburg permitted us to work on board the F.R.V. "Walther Herwig". Cruise-leaders S. Ehrich, H. Dornheim, U. Damm, as well as Captain Hinners and Captain Seelmann, supported us during our stay. S. Baumung, S. Bräger, S. Clorius, F. Jachmann, K. Janssen and I. Prieto helped with the fieldwork. The "Verein der Freunde und Förderer der Inselstation der Vogelwarte Helgoland e.V." gave financial support. F. Bairlein, F. Trillmich and R. P. Wilson made valuable suggestions to improve earlier versions of this paper. R. P. Wilson improved our English. We thank all of them very much. 


\section{LITERATURE CITED}

Beal, K. G. \& Khamis, H. J., 1991. A problem in statistical analysis: simultaneous inference. - Condor 93, 1023-1025.

Bezzel, E., 1985. Kompendium der Vögel Mitteleuropas. Nonpasseriformes - Nichtsingvögel. Aula, Wiesbaden. $792 \mathrm{pp}$.

Brockmann, H. J. \& Barnard, C. J., 1979. Kleptoparasitism in birds. - Anim. Behav. 27, 487-514.

Camphuysen, C. J., 1993. Een verkennend onderzoek: De exploitatie van op zee overboord geworpen vis en snijafval door zeevogels. - Het Vogeljaar 41, 106-114.

Camphuysen, C. J., Calvo, B., Durinck, J., Ensor, K., Follestad, A., Furness, R. W., Garthe, S., Leaper, G., Skov, H., Tasker, M. L. \& Winter, C. J. N., 1995. Consumption of discards by seabirds in the North Sea. - NIOZ-rapp. 1995-5, 1-202.

Camphuysen, C. J. \& Garthe, S., 1997. An evaluation of the distribution and scavenging habits of northern fulmars Fulmarus glacialis in the North Sea. - ICES J. mar. Sci. 54, 654-683.

Cramp, S. \& Simmons, K. E. L. (Eds.), 1977. Handbook of the birds of Europe, the Middle East and North Africa. The birds of the Western Palaearctic. Oxford Univ Press, Oxford, 1, 1-722.

Cramp, S. \& Simmons, K. E. L. (Eds.), 1983. Handbook of the birds of Europe, the Middle East and North Africa. The birds of the Western Palaearctic. Oxford Univ Press, Oxford, 3, 1-913.

Dändliker, G. \& Mülhauser, G., 1988. L'exploitation des déchets de chalutage par les oiseaux de mer au large des Orcades et des Shetland (NordEst Atlantique). - Nos Oiseaux 39, 257-288.

Erikstad, K. E., Bustnes, J. O. \& Jacobsen, O., 1988. Duration of ship-following by kittiwakes Rissa tridactyla in the Barents Sea. - Polar Res. 6, 191-194.

Furness, R. W., 1987. Kleptoparasitism in seabirds. In: Seabirds: feeding biology and role in marine ecosystems. Ed. by J. P. Croxall. Cambridge Univ Press, Cambridge, 77-100.

Furness, R. W., 1992. Implications of changes in net mesh size, fishing effort and minimum landing size regulations in the North Sea for seabird populations. - JNCC Rep. 133, 1-60.

Furness, R.W., Ensor, K. \& Hudson, A. V., 1992. The use of fishery waste by gull populations around the British Isles. - Ardea 80, 105-113.

Garthe, S. \& Hüppop, O., 1994. Distribution of ship-following seabirds and their utilization of discards in the North Sea in summer. - Mar. Ecol. Prog. Ser. 106, 1-9.

Hamer, K. C., Furness, R. W. \& Caldow, R. W. G., 1991. The effects of changes in food availability on the breeding ecology of great skuas Catharacta skua in Shetland. - J. Zool. 223, 175-188.

Hudson, A. V. \& Furness, R. W., 1989. The behaviour of seabirds foraging at fishing boats around Shetland. - Ibis 131, 225-237.

Noordhuis, R. \& Spaans, A. L., 1992. Interspecific competition for food between herring Larus argentatus and lesser black-backed gulls $L$. fuscus in the Dutch Wadden Sea area. - Ardea 80, 115-132.

Oro, D., 1995. The influence of commercial fisheries in daily activity of Audouin's gull Larus audouinii in the Ebro Delta, NE Spain. - Ornis fenn. 72, 154-158.

Oro, D., 1996. Interspecific kleptoparasitism in Audouin's gull Larus audouinii at the Ebro Delta, northeast Spain: a behavioural response to low food availability. - Ibis 138, 218-221.

Oro, D., Jover, L. \& Ruiz, X., 1996. Influence of trawling activity on the breeding ecology of a threatened seabird, Audouin's gull Larus audouinii. - Mar. Ecol. Prog. Ser. 139, 19-29.

Porter, J. M. \& Sealy, S. G., 1982. Dynamics of seabird multispecies feeding flocks: age-related feeding behaviour. - Behaviour 81,91-109.

Russel, J. O. \& Montevecchi, W. A., 1996. Predation on adult puffins Fratercula arctica by great black-backed gulls Larus marinus at a Newfoundland colony. - Ibis 138, 791-794

Ruiz, X., Oro, D., Martinez-Vilalta, A. \& Jover, L., 1996. Feeding ecology of Audouin's gulls Larus audouinii in the Ebro Delta. - Colon. Waterbirds 19, 68--74.

Shealer, D. A. \& Burger, J., 1993. Effects of interference competition on the foraging activity of tropical roseate terns. - Condor 95, 322-329.

Thompson, D. B. A., 1986. The economics of kleptoparasitism: optimal foraging, host and prey selection by gulls. - Anim. Behav. 34, 1189-1205. 